\title{
PEMILIHAN ALAT PANCANG MENGGUNAKAN EXPERT CHOICE
}

\author{
Joko Yulianto ${ }^{1}$ \\ ${ }^{1)}$ Doktor Teknik Sipil,Universitas Diponegoro, Jl.Hayam Wuruk No. 5-7, Semarang 50241; HP. \\ 08125873374. \\ Email:ylnt_jk@yahoo.com
}

\begin{abstract}
ABSTRAK
Hampir semua konstruksi bangunan bertingkat memerlukan pondasi tiang pancang untuk mendukung beban di atasnya. Alat pancang yang dapat digunakan adalah drop hammer, single-acting hammer, double-acting hammer, differential-acting, diesel hammer, vibratory hammer, dan hydraulic jackingin pile. Banyak faktor yang mempengaruhi pemilihan alat pancang. Metoda AHP (Analytic Hierarchy Process) yang diaplikasikan dengan software Expert Choice (EC) dapat membantu memilih alat pancang yang cocok. Proyek pemancangan di Pabrik Gula Trangkil menggunakan alat hydraulic jackin pile. Penelitian ini bertujuan untuk memeriksa alternatif pemilihan alat pancang menggunakan software Expert Choice (EC). Metodologi penelitian ini dibagi dalam 3 tahap yaitu tahap pertama adalah studi pustaka dan survai awal, tahap kedua adalah pengumpulan data, dan tahap ketiga adalah analisis dan kesimpulan. Pemancangan sampai kedalaman $12 \mathrm{~m}$ pada jenis tanah lanau menggunakan tiang pancang beton ukuran $25 \times 25 \mathrm{~cm}$. Hasil analisis menunjukkan bahwa alat pancang yang cocok adalah hydraulic jacking-in pile dengan tingkat kecocokan 44,5\%. Sedangkan tingkat kecocokan alat yang lain adalah $28,7 \%$ untuk diesel hammer dan $26,9 \%$ untuk vibratory hammer.
\end{abstract}

Kata kunci: $A H P$, alat pancang, $E C$.

\begin{abstract}
Most high building constructions need pile driving foundation to support the load. The types of pile driving equipment are drop hammer, single-acting hammer, double-acting hammer, differentialacting, diesel hammer, vibratory hammer, and hydraulic jacking-in pile. There are many factors influence the selection of pile driving equipment. AHP method is applied by Expert Choice (EC) software that can help choose the suitable pile driving equipment. The pile driving project at Pabrik Gula Trangkil used hydraulic jack-in pile. This research objective is to check the alternatives of the selection of pile driving equipment using EC software. This research methodology used is divided into 3 steps; the first step is literature review and pre-survey, the second step is data aggregation, and the third step is analysis and resume. The size of the driven pile $25 \times 25 \mathrm{~cm}$ was used to drive in the siltty soil until $12 \mathrm{~m}$ in depth. The outcome of this analysis explained that the suitable pile driving equipment was hydraulic jack-in pile with 44,5\% compatibility. Besides, diesel hammer had 28,7\% and vibratory hammer had $26,9 \%$ compatibility.
\end{abstract}

Keyword: AHP, pile driving equipment, EC.

\section{PENDAHULUAN}

Hampir semua konstruksi bangunan bertingkat memerlukan pondasi tiang untuk mendukung beban bangunan. Salah satu pondasi tiang yang banyak digunakan adalah tiang pancang. Pondasi tiang pancang dilaksanakan dengan pemancangan. Alat yang dapat digunakan untuk pemancangan adalah: drop hammer, steam single-acting hammer, steam double-acting hammer, steam differential-acting hammer, diesel hammer, vibratory hammer, dan hydraulic jacking-in pile ([1]; [2]; [3]; [4]). Pemilihan alat pancang yang cocok untuk proyek dengan mempertimbangkan faktor-faktor: ukuran tiang, jumlah tiang, karakter tanah, lokasi proyek, dan topografi lokasi ([4]; [5]). Sedangkan [3] memberikan pertimbangan pemilihan alat adalah: faktor komersial (keberadaan dan ukuran alat), dampak kebisingan, pengaruh getaran, hambatan alat, batasan jarak ruang gerak. Penelitian [6] menggunakan aspek daya dukung tiang, lingkungan, biaya, dan pengoperasian alat untuk memilih alat pancang.

Pemilihan alat pancang melibatkan banyak faktor pertimbangan sehingga akan sangat sulit memilih alat yang efisien. Oleh karena itu diperlukan metoda yang dapat mengatasi kesulitan itu. Salah satu metoda yang dapat digunakan adalah AHP (Analytic Hierarchy Process). Metoda AHP dapat 
mengakomodir data-data kualitatif dan kuantitatif. AHP (Analytic Hierarchy Process) adalah metode yang dapat membantu pengambil keputusan menghadapi masalah komplek [7]. Software pendukung $A H P$ yaitu Expert Choice (EC). Beberapa penelitian telah sukses diaplikasikan dengan EC di lapangan, misalnya pemasok konstruksi [8], lokasi internasional [9], perencanaan sumberdaya [10], pemasangan pipa [11]. Berdasar kesuksesan mereka maka diharapkan EC dapat pula membantu memilih alat pancang yang cocok. Penelitian ini mengambil studi kasus proyek di Pabrik Gula Trangkil, Kabupaten Pati, Provinsi Jawa Tengah. Proyek pemancangan menggunakan alat hydraulic jack-in pile. Apakah alat ini yang paling cocok? Oleh karena itu penelitian ini bertujuan untuk memeriksa alternatif pemilihan alat pancang menggunakan software Expert Choice (EC).

\begin{abstract}
Alat Pancang
Terdapat 7 jenis alat pancang yang dapat digunakan untuk memancang tiang pancang. Namun beberapa jenis alat sudah jarang digunakan untuk memancang tiang pancang beton. Misalnya steam single-acting hammer, steam double-acting hammer, dan steam differential-acting hammer sekarang jarang digunakan karena alasan lingkungan dan kepraktisannya. Selain itu juga karena besarnya instalasi generator mesin uap atau udara yang harus diatur di setiap lokasi. Alat tersebut utamanya digunakan untuk memancang steel tube pile dan sheet pile [12]. Demikian pula drop hammer yang memiliki kecepatan pukulan rendah sehingga tidak digunakan umum kecuali untuk jumlah tiang yang sedikit [13]. Selain itu drop hammer cocok digunakan pada proyek terpencil, jumlah tiang sedikit, dan waktu penyelesaian bukan faktor utama [4]. Oleh karena itu kajian difokuskan pada alat diesel hammer, vibratory hammer, dan hydraulic jacking-in pile. Ketiga alat tersebut mempunyai peluang yang hampir sama untuk digunakan dalam proyek pemancangan tiang pancang beton.
\end{abstract}

\title{
Diesel Hammer
}

Mempunyai mobilitas tinggi, konsumsi bahan bakar rendah, efisien dioperasikan pada suhu rendah [1], bobotnya ringan, dan dimensinya kecil [13]. Dapat digunakan dengan baik pada tanah kohesif atau lapisan sangat padat dan tidak dapat dioperasikan dengan baik pada tanah lunak [4].

\section{Vibratory Hammer}

Alat ini menekan tiang dengan getaran sehingga dapat mengurangi getaran pemancangan, mengurangi kebisingan, dan mempunyai kecepatan penetrasi yang bagus. Hasil terbaik digunakan pada tanah non kohesif, agak bagus pada tanah berlempung dan berlanau [1]. Secara khusus efektif digunakan pada tanah non kohesif jenuh air dan sulit memancang pada tanah pasir kering atau tanah kohesif yang tidak merespon getaran [4].

\section{Hydraulic Jacking-In Pile}

Menggabungkan teknik menggenggam dan menekan atau menarik, sedikit kebisingan dan getaran. Selain itu sangat cocok digunakan di area yang terbatas ruang geraknya. Penggunaan energi lebih efisien dari single, double, differential-acting, dan diesel hammer [4].

\section{Kriteria Pemilihan Alat Pancang}

Pemilihan alat pancang yang tepat pada suatu kondisi pemancangan akan memberikan efisiensi pekerjaan dan nilai ekonomis. Kriteria yang akan digunakan sebagai dasar pemilihan alat pancang adalah sebagai berikut:

1. Dampak lingkungan (DL); meliputi kebisingan, polusi, dan getaran yang ditimbulkan saat pengoperasian alat.

2. Biaya Pelaksanaan (BP); meliputi biaya pemancangan dan biaya mobilisasi peralatan.

3. Jumlah tiang (JT); 476 tiang pancang dengan panjang $6 \mathrm{~m}$ sehingga total panjang tiang menjadi 2856 $\mathrm{m}$.

4. Ukuran tiang (UT); pemancangan menggunakan tiang pancang beton bujursangkar $25 \mathrm{x} 25 \mathrm{~cm}$ dengan panjang $6 \mathrm{~m}$.

5. Karakter tanah (KT); pemancangan pada tanah lanau dengan daya dukung tanah pada kedalaman $12 \mathrm{~m}$ sebesar $200 \mathrm{~kg} / \mathrm{cm}^{2}$ sedang kedalaman $<12 \mathrm{~m}$ sebesar $5-85 \mathrm{~kg} / \mathrm{cm}^{2}$.

6. Lokasi proyek (LP); lokasi proyek di daerah pedesaan, area proyek luas, dan akses jalan mudah.

7. Topografi lokasi (TL); topografi lokasi datar dan padat.

8. Keberadaan alat (KA); meliputi pengoperasian alat dan hambatan alat. 


\section{Expert Choice}

AHP (Analytic Hierarchy Process) adalah teori pengukuran melalui perbandingan berpasangan dan bersandar pada pertimbangan ahli untuk memperoleh skala prioritas [14]. AHP merupakan metodologi pengambilan keputusan untuk banyak sifat dan alternatif masalah [10]. AHP adalah sebuah rancangan pendekatan keputusan untuk membantu dalam solusi masalah kriteria komplek dengan sejumlah bidang aplikasi [15]. Metode ini telah ditemui menjadi efektif dan pendekatan praktek yang dapat mempertimbangkan keputusan tidak berstruktur dan komplek [16]. AHP merupakan metodologi desain yang komprehensif dan sangat kuat untuk memudahkan mengambil keputusan dengan menggunakan data empirik seperti halnya pertimbangan pengambil keputusan. Pendekatan ini cocok untuk membuat pilihan antara beberapa alternatif sistem komplek dan menyediakan perbandingan dari bagian masalah dalam bentuk hirarkikal. AHP diimplementasikan dengan software Expert Choice (EC). EC memudahkan analisis AHP.

\section{METODE}

Penelitian ini dibagi menjadi 3 tahap.Tahap pertama adalah studi pustaka dan survai awal. Tahap kedua adalah pengumpulan data.Tahap ketiga adalah analisis data dan kesimpulan. Penelitian ini menggunakan metode observasi dan survai. Penelitian dilakukan di Pabrik Gula Trangkil, Kabupaten Pati, Provinsi Jawa Tengah pada tanggal 7 - 8 Desember 2012. Data yang dikumpulkan berupa: data sondir, gambar rencana titik-titik pondasi, ukuran tiang pancang, hasil pengamatan lokasi, dan hasil wawancara tentang biaya pelaksanaan. Data-data yang terkumpul dianalisis menggunakan $E C$ untuk menentukan bobot kriteria dan alternatif. Analisis penelitian ini menggunakan $A H P$ yang diimplementasikan dengan software Expert Choice.Tahap menggunakan $A H P$ dan $E C$ yaitu model hirarkikal, perbandingan berpasangan kriteria dan alternatif, dan analisis sensitivitas [11].

\section{Model Hirarkikal}

Struktur model AHP membagi masalah dalam kluster sederhana yang mewakili tingkat berbeda dalam struktur hirarkikal. Dekomposisi dilaksanakan dari atas ke bawah, mulai dari tujuan, ke kriteria, ke alternatif akhir. Struktur model penelitian ini dibagi dalam 3 bagian yaitu tujuan (memeriksa alternatif pemilihan alat pancang), kriteria (DL, BP, JT, UT, KT, LP, TL, dan KA), dan alternatif (diesel hammer, vibratory hammer, hydraulic jack-in pile). Struktur model AHP penelitian ini ditunjukkan dalam Gambar 1.

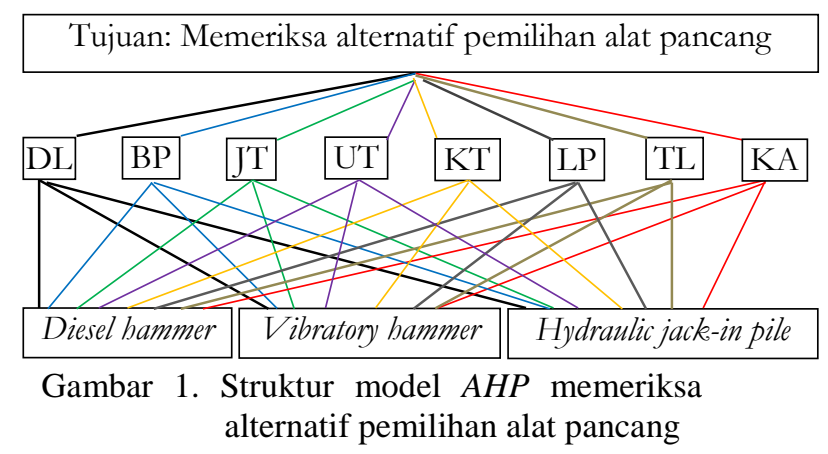

\section{Perbandingan Berpasangan}

Perbandingan berpasangan memberikan nilai tiap kluster untuk mengukur kepentingan tiap tingkat dalam hirarki. Tiap elemen tunggal dievaluasi menggunakan perbandingan berpasangan. Perbandingan dibuat pada 9 titik skala, yang disebut "fundamental scale of Saaty" yang ditunjukkan dalam Tabel 1 dan 2. Pertimbangan numerik didirikan pada tiap tingkat hirarki sehingga membentuk matrik berpasangan. $\mathrm{n}$ merupakan sejumlah kriteria dalam tingkat hirarki tertentu, $\mathrm{m}$ merupakan sejumlah alternatif, oleh karena itu ada $\mathrm{n}$ matrik dengan $\mathrm{m}$ baris dan $\mathrm{m}$ kolom dalam tingkat itu yang ditunjukkan dalam Tabel 3. Semua matrik berpasangan mempunyai 2 sifat dasar yaitu diagonal utama bernilai 1 (tiap kriteria dibandingkan dengan dirinya sendiri) dan matrik kebalikan $\left(\mathrm{i}_{\mathrm{a}} \mathrm{j}_{\mathrm{b}}=1 /\left(\mathrm{i}_{\mathrm{b}} \mathrm{j}_{\mathrm{a}}\right) ; \mathrm{k}_{\mathrm{c}} \mathrm{l}_{\mathrm{d}}=\right.$ $\left.1 /\left(\mathrm{k}_{\mathrm{d}} \mathrm{l}_{\mathrm{c}}\right)\right)$.

Secara umum disetujui bahwa prioritas kriteria dapat diestimasi dengan menemukan eigenvector utama w dari matrik A [17] yang diberikan dengan Persamaan 1.

$\mathrm{A}_{\mathrm{w}}=\lambda_{\text {mak }} \cdot \mathrm{W}$ 
Ketika vektor w dinormalisasi akan menjadi vektor prioritas kriteria dengan mematuhi tujuan. $\lambda_{\max }$ adalah eigenvalue terbesar dari matrik A dan eigenvector $\mathrm{w}$ yang sesuai hanya nilai positif.

Konsistensi matrik pertimbangan dapat ditentukan dengan sebuah ukuran yang disebut consistency ratio (CR) yang didefinisikan dengan Persamaan 2 [17].

$\mathrm{CR}=\mathrm{CI} / \mathrm{RI}$

$C I$ merupakan indek konsistensi $=\left(\lambda_{\operatorname{mak}}-\mathrm{n}\right) /(\mathrm{n}-1), \lambda_{\operatorname{mak}}$ adalah eigenvalue maksimum, $\mathrm{n}$ adalah dimensi matrik, dan RI adalah indek acak yang ditunjukkan dalam Tabel 4.

Jika CR matrik tinggi, berarti bahwa pertimbangan masukan tidak konsisten dan tidak riliabel. Secara umum, rasio konsistensi < 0,10 dipertimbangkan diterima. Jika nilai tinggi, pertimbangan tidak reliabel dan harus dimunculkan lagi. Menggunakan prosedur yang sama, prioritas lokal alternatif dengan mematuhi setiap kriteria dapat diestimasi. Langkah terakhir prosedur terdiri dari sebuah kesatuan dari prioritas lokal elemen tingkat yang berbeda dalam urutan untuk menghasilkan prioritas final dari alternatif. Daftar final, dihasilkan dengan penjumlahan semua eigenvector, adalah sebuah vektor yang menyediakan pengukuran dari bagian yang dimainkan oleh tiap alternatif dalam mencapai tujuan awal.

Sintesis alternatif dapat dilakukan dengan 2 pendekatan yaitu distributive mode dan ideal mode. Distributive mode menggunakan normalisasi jumlah prioritas lokal untuk kesatuan sedangkan ideal mode menggunakan normalisasi dengan membagi skor tiap alternatif oleh skor alternatif terbaik tiap kriteria [7]. Jika dalam sistem tertutup (misalnya tidak ada alternatif akan ditambahkan atau dipindahkan) dan dalam sistem terbuka (misalnya alternatif dapat ditambahkan atau dipindahkan) di mana alternatif pilihan tergantung pada alternatif lain maka boleh digunakan distributive mode. Sedangkan bila dalam sistem terbuka dan tidak ingin alternatif lain mempengaruhi hasil maka ideal mode direkomendasikan [18].

Tabel 1. Skala fundamental Saaty[15]

\begin{tabular}{cl}
\hline $\begin{array}{c}\text { Nilai } \\
\left(\mathrm{i}_{\mathrm{a} j \mathrm{~b}} ; \mathrm{k}_{\mathrm{c}} \mathrm{l}_{\mathrm{d}}\right)\end{array}$ & \multicolumn{1}{c}{ Penjelasan } \\
\hline 1 & Dua faktor sama pentingnya \\
3 & Satu faktor sedikit lebih penting \\
5 & Satu faktor kuat lebih penting \\
7 & Satu faktorsangat kuat lebih penting \\
9 & Satu faktor mutlak lebih penting \\
$2,4,6,8$ & Nilai lanjutan \\
$\mathrm{a}, \mathrm{b}=(1,2,3, \ldots \mathrm{n}=$ jumlah kriteria); \\
$\mathrm{c}, \mathrm{d}=(1,2,3, \ldots \mathrm{m}=$ jumlah alternatif $)$ \\
\hline
\end{tabular}

Tabel 2. Perbandingan berpasangan kriteria [15]

\begin{tabular}{|c|c|c|c|c|c|c|c|}
\hline \multirow{2}{*}{$\begin{array}{l}1 \\
j\end{array}$} & & \multicolumn{6}{|c|}{ Kriteria } \\
\hline & & 1 & 2 & 3 & 4 & $\ldots$ & $\mathrm{n}$ \\
\hline \multirow{8}{*}{ 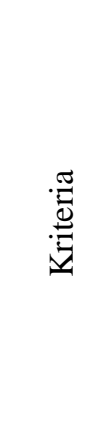 } & 1 & 1 & $\mathrm{i}_{1} \mathrm{j}_{2}$ & $\mathrm{i}_{1} \mathrm{j}$ & $\mathrm{i}_{1} \mathrm{j}_{4}$ & $\ldots$ & $\mathrm{i}_{1} \mathrm{j}_{\mathrm{n}}$ \\
\hline & 2 & $\mathrm{i}_{2} \mathrm{j}$ & 1 & $\begin{array}{l}3 \\
\mathrm{i}_{2} \mathrm{j}\end{array}$ & $\mathrm{i}_{2} \mathrm{j}_{4}$ & $\ldots$ & $i_{2} j_{n}$ \\
\hline & & 1 & & 3 & & & \\
\hline & 3 & $i_{3} j$ & $i_{3} j_{2}$ & 1 & $i_{3} j_{4}$ & $\ldots$ & $i_{3} j_{n}$ \\
\hline & 4 & $\mathrm{i}_{4} \mathrm{j}$ & $\mathrm{i}_{4} \mathrm{j}_{2}$ & $i_{4} j$ & 1 & $\ldots$ & $i_{4} j_{n}$ \\
\hline & & 1 & & 3 & & & \\
\hline & .. & $\ldots$ & $\ldots$ & $\ldots$ & & $\ldots$ & $\ldots$ \\
\hline & $\mathrm{n}$ & $i_{n} j$ & $\mathrm{i}_{\mathrm{n}} \mathrm{j}_{2}$ & $i_{n} j$ & $i_{n} j_{4}$ & $\ldots$ & $i_{n} j_{n}=1$ \\
\hline
\end{tabular}


$\mathrm{i}_{\mathrm{a}} \mathrm{j}_{\mathrm{b}}:(\mathrm{a}=1, \ldots \mathrm{n} ; \mathrm{b}=1, \ldots \mathrm{n})=$ nilai lihat Tabel 1

Tabel 3. Perbandingan berpasangan alternatif [15]

\begin{tabular}{|c|c|c|c|c|c|c|}
\hline \multicolumn{7}{|c|}{ Kriteria i $(\mathrm{i}-->1,2, \ldots \mathrm{n})$} \\
\hline \multirow{2}{*}{$\mathrm{k}$} & & \multicolumn{5}{|c|}{ Alternatif } \\
\hline & & 1 & 2 & 3 & $\ldots$ & $\mathrm{m}$ \\
\hline & 1 & 1 & $\mathrm{k}_{1} \mathrm{l}_{2}$ & $\mathrm{k}_{1} \mathrm{l}_{3}$ & $\ldots$ & $\mathrm{k}_{1} \mathrm{l}_{\mathrm{m}}$ \\
\hline & 2 & $\mathrm{k}_{2} \mathrm{l}_{1}$ & 1 & $\mathrm{k}_{2} \mathrm{l}_{3}$ & $\ldots$ & $\mathrm{k}_{2} \mathrm{l}_{\mathrm{m}}$ \\
\hline & 3 & $\mathrm{k}_{3} \mathrm{l}_{1}$ & $\mathrm{k}_{3} \mathrm{l}_{2}$ & 1 & $\ldots$ & $\mathrm{k}_{3} \mathrm{l}_{\mathrm{m}}$ \\
\hline Eే &.$\cdot$ & $\cdots$ & $\cdots$ & $\cdots$ & $\cdots$ & $\cdots$ \\
\hline$\stackrel{\frac{g}{2}}{<}$ & $\mathrm{m}$ & $\mathrm{k}_{\mathrm{m}} \mathrm{l}_{1}$ & $\mathrm{k}_{\mathrm{m}} \mathrm{l}_{1}$ & $\mathrm{k}_{\mathrm{m}} \mathrm{l}_{1}$ & $\ldots$ & $\mathrm{k}_{\mathrm{m}} \mathrm{l}_{\mathrm{m}}=1$ \\
\hline
\end{tabular}

Tabel 4. Indek acak [17]

\begin{tabular}{|l|l|l|l|l|l|l|l|l|}
\hline $\mathrm{n}$ & 3 & 4 & 5 & 6 & 7 & 8 & 9 & 10 \\
\hline \multirow{2}{*}{$\mathrm{RI}$} & 0,5 & 0,9 & 1,1 & 1,2 & 1,3 & 1,4 & 1,4 & 1,4 \\
& 8 & 0 & 2 & 4 & 2 & 1 & 5 & 9 \\
\hline
\end{tabular}

Tabel 5. Karakteristik kriteria dan alternative

\begin{tabular}{|c|c|c|c|}
\hline \multirow[t]{2}{*}{ Kriteria } & \multicolumn{3}{|c|}{ Alternatif } \\
\hline & Diesel hammer & Vibratory hammer & Hydraulic jack-in pile \\
\hline Dampak lingkungan (DL) & 1 & 1,394 & 1,742 \\
\hline Biaya pemancangan (BP) & 5,667 & 2,667 & 1 \\
\hline Jumlah tiang (JT) & Produksi rendah & Produksi sedang & Produksi tinggi \\
\hline Ukuran tiang (UT) & $>40 \times 40 \mathrm{~cm}$ & $>20 \times 20 \mathrm{~cm}$ & $>20 \times 20 \mathrm{~cm}$ \\
\hline Karakter tanah (KT) & Tanah keras & Tanah berpasir & Tanah lunak \\
\hline Lokasi proyek (LP) & $\begin{array}{l}\text { Cocok di pedesaan, area } \\
\text { sempit, akses jalan kecil }\end{array}$ & $\begin{array}{l}\text { Cocok di perkotaan, area } \\
\text { sempit, akses jalan kecil }\end{array}$ & $\begin{array}{l}\text { Cocok di perkotaan, area } \\
\text { luas, akses jalan besar }\end{array}$ \\
\hline Topografi lokasi (TL) & Datar, tidak harus padat & Datar, tidak harus padat & Harus datar dan padat \\
\hline Keberadaan alat (KA) & $\begin{array}{l}\text { Kebutuhan energi tinggi, } \\
\text { perlu crane }\end{array}$ & $\begin{array}{l}\text { Kebutuhan energi } \\
\text { sedang, perlu crane }\end{array}$ & $\begin{array}{l}\text { Kebutuhan energi rendah, } \\
\text { crane sudah tersedia }\end{array}$ \\
\hline
\end{tabular}

\section{Analisis Sensitivitas}

Data masukan sedikit dimodifikasi dalam rangka mengamati dampak pada hasil. Jika urutan tidak berubah maka hasil dikatakan tegap atau kuat. Analisis sensitivitas terbaik dilakukan dengan hubungan interaktif secara grafik. EC menyediakan analisis sensitivitas yang berlainan dimana perbedaan utama itu perwakilan berbagai grafik [7].

\section{HASIL DAN PEMBAHASAN}

Data-data hasil wawancara dan pengamatan ditunjukkan dalam Tabel 5 yang selanjutnya digunakan sebagai dasar pemodelan. Kriteria disusun dalam software EC dan dilakukan pembobotan selanjutnya memasukkan alternatif dan pembobotannya pada masing-masing kriteria.

\section{Model Hirarkikal}

Hirarki model dibuat berdasar Gambar 1 dalam software EC yang ditunjukkan pada Gambar 2. Sebelah kiri menunjukkan kriteria dan sebelah kanan menunjukkan alternatif. Terdapat 8 kriteria (DL, BP, JT, UT, KT, LP, TL, dan KA) yang akan digunakan untuk memilih alternatif alat pancang pada 
lokasi proyek. Terdapat 3 alternatif (diesel hammer, vibratory hammer, dan hydraulic jack-in pile) pada masing-masing kriteria. Ketiga alternatif itu akan dirangking untuk masing-masing kriteria sehingga diperoleh rangking alternatif secara global.

\begin{tabular}{|c|c|}
\hline \multicolumn{2}{|c|}{ 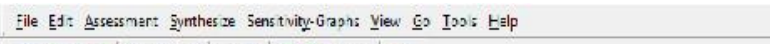 } \\
\hline \\
\hline 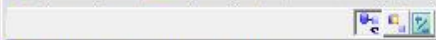 & 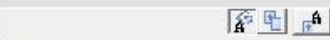 \\
\hline \multirow{2}{*}{$\begin{array}{l}\text { Goal: Alternatif pemilihan alat pancang } \\
\square \text { ㅁ․ (L: . 288) }\end{array}$} & Diesel Ilammer \\
\hline & Vibratory Hammer \\
\hline$\square \mathrm{BP}(\mathrm{L}:$.228) & Hydraulic Jack-in Pile \\
\hline$\square \mathrm{JT}(\mathrm{L}:$. 152) & \\
\hline \multicolumn{2}{|l|}{ UT (L: .107) } \\
\hline \multicolumn{2}{|l|}{ KT (L: .083) } \\
\hline \multicolumn{2}{|l|}{ LP (L: .058) } \\
\hline \multirow{2}{*}{ TL (L: .040) } & $1+\longdiv { 1 1 } +$ \\
\hline & 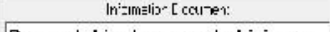 \\
\hline & $\begin{array}{l}\text { Dampak. Lingkunujan. kebisinyan, } \\
\text { getaran. polusı } \\
\text { diesel liamume paling linggi } \\
\text { herdampak lıngkungan. vhrratory } \\
\text { dan lydradic sedikil berdanpak }\end{array}$ \\
\hline
\end{tabular}

Gambar 2. Model hirarki

\section{Perbandingan Berpasangan}

Pembobotan dan perbandingan berpasangan antar kriteria dan antara kriteria dengan alternatif dilakukan menggunakan pendekatan distributive mode. Masing-masing kriteria mempunyai bobot sebagai berikut: DL 28,8\%; BP 22,8\%; JT 15,2\%; UT 10,7\%; KT 8,3\%; LP 5,8\%; TL 4,8\%; dan KA $3,6 \%$. Bobot tersebut menunjukkan besarnya pengaruh kriteria dalam pemilihan alternatif alat pancang.Hasil pembobotan alternatif secara keseluruhan ditunjukkan pada Gambar 3. Bobot alternatif terhadap kedelapan kriteria ditunjukkan pada Tabel 6.

Bobot alternatif secara keseluruhan dapat dihitung dengan mengalikan masing-masing bobot alternatif dengan bobot kriteria, selanjutnya hasil perkalian dijumlahkan.Kriteria DL dan BP memberikan kontribusi $51,6 \%$. DL terkecil ditimbulkan dari hydraulic jack-in pile sehingga memberikan peluang $64,5 \%$. BP terkecil bila menggunakan diesel hammer dengan peluang 43,6\%.

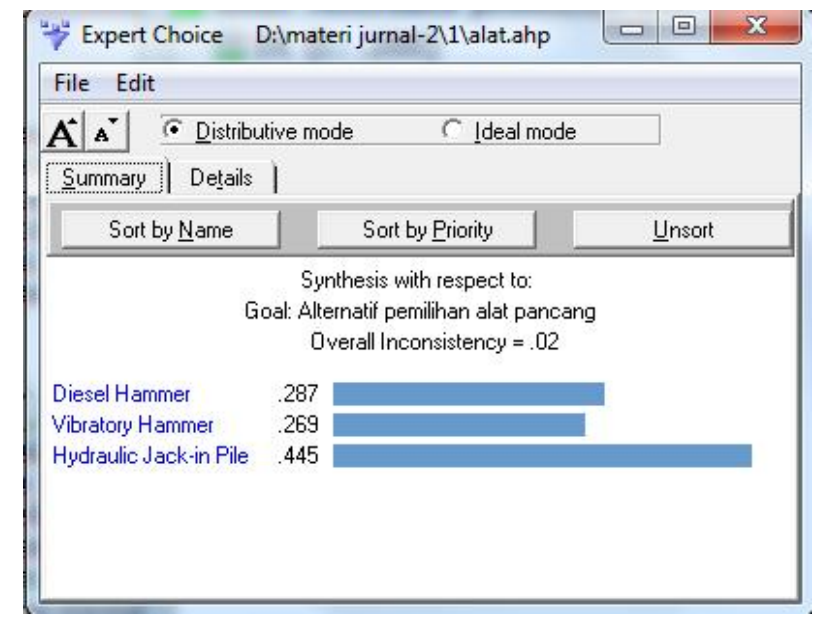

Gambar 3. Prioritas model dan hasil sintesis dengan distributive mode

Tabel 6.Bobot alternative 


\begin{tabular}{lllc}
\hline Kriteria & $\begin{array}{c}\text { Diesel } \\
\text { hammer }\end{array}$ & $\begin{array}{c}\text { Alternatif } \\
\text { hammer }\end{array}$ & $\begin{array}{c}\text { Hydraulic } \\
\text { jack-in } \\
\text { pile }\end{array}$ \\
\hline $\begin{array}{l}\text { DL } \\
(28,8 \%)\end{array}$ & $11,4 \%$ & $24,2 \%$ & $64,5 \%$ \\
BP & $43,6 \%$ & $31,3 \%$ & $25,0 \%$ \\
$(22,8 \%)$ & $32,0 \%$ & $16,9 \%$ & $51,0 \%$ \\
JT & & & $40,0 \%$ \\
$(15,2 \%)$ & $20,0 \%$ & $40,0 \%$ & $50,0 \%$ \\
UT & $37,5 \%$ & $12,5 \%$ & $15,8 \%$ \\
$(10,7 \%)$ & $47,4 \%$ & $36,8 \%$ & $25,0 \%$ \\
KT & & $37,5 \%$ & $52,6 \%$ \\
$\begin{array}{l}(8,3 \%) \\
\text { (5,8\%) }\end{array}$ & $37,5 \%$ & $26,3 \%$ & \\
TL & & & \\
$(4,8 \%)$ & $21,1 \%$ & & \\
KA & & & \\
$(3,6 \%)$ & & & \\
\hline
\end{tabular}

\section{Analisis Sensitivitas}

Hasil model ditunjukkan pada Gambar 4 dengan grafik performance dan dynamic. Urutan alternatif adalah: hydraulic jack-in pile, diesel hammer, dan vibratory hammer dengan bobot secara berurutan: $44,5 \% ; 28,7 \%$; dan $26,9 \%$.
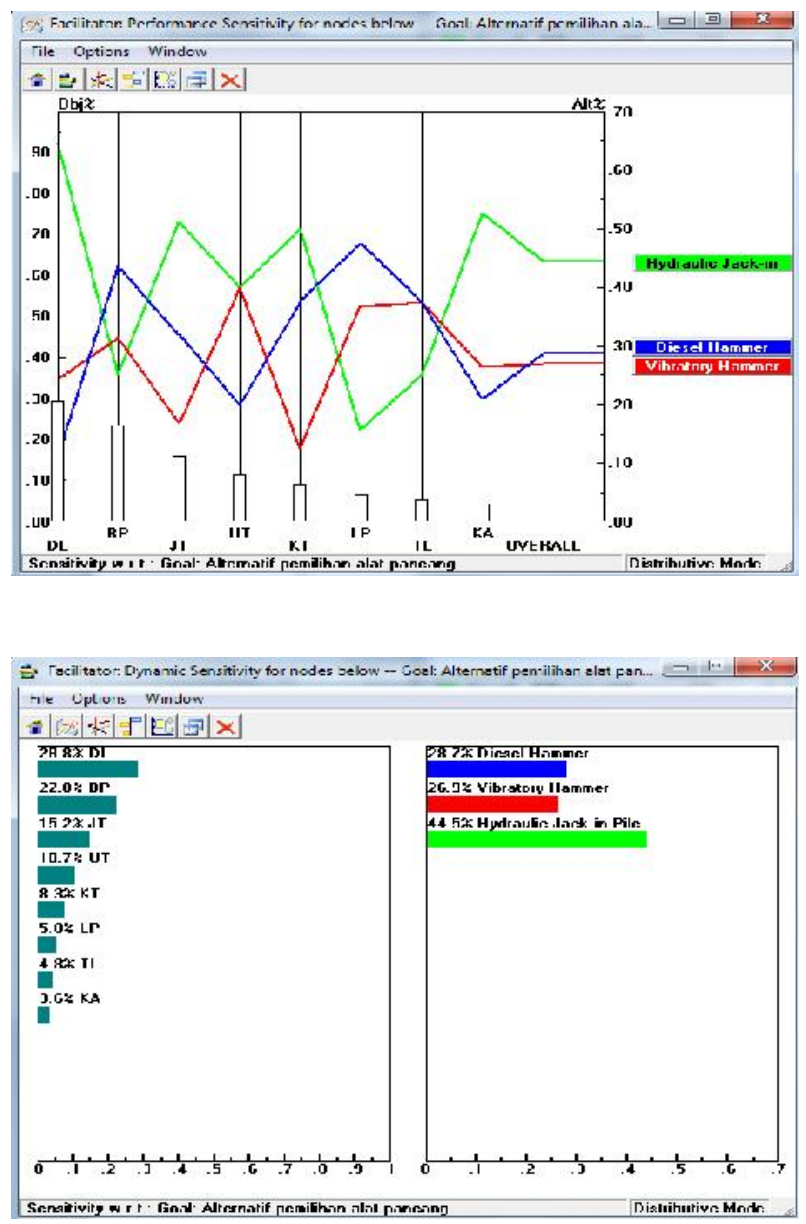
Gambar 4. Grafik analisisdistributive mode: performance and dynamic analysis

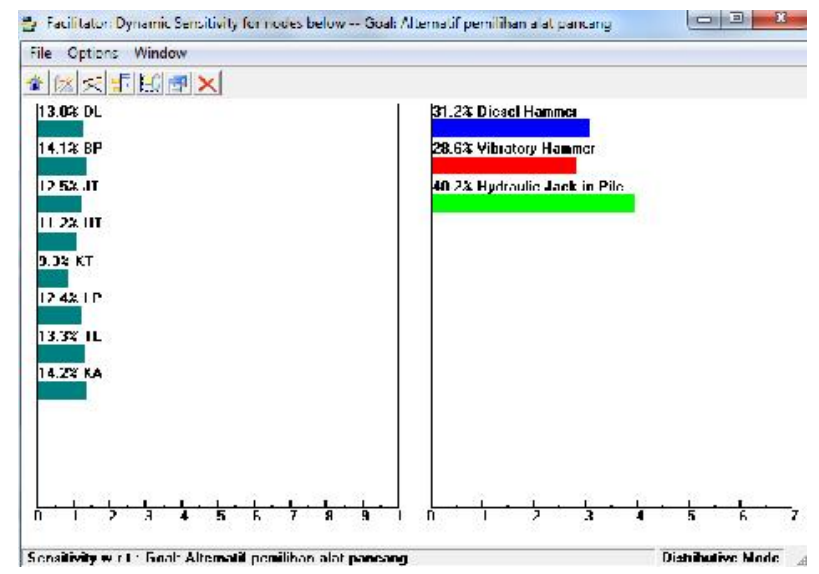

Gambar 5. Analisis sensitivitas distributive mode modifikasi: dynamic analys

Analisis sensitivitas dilakukan untuk memeriksa kehandalan model hirarki yang dibangun.Analisis sensitivitas dilakukan dengan memberikan sedikit perubahan masukan pada grafik performance. Hasil perubahan masukan menghasilkan urutan alternatif yang tidak berubah seperti ditunjukkan pada Gambar 5. Bobot hasil perubahan adalah: hydraulic jack-in pile 40,2\%; diesel hammer 31,2\%; dan vibratory hammer $28,6 \%$. Selain itu, jika dampak lingkungan tidak diperhatikan (karena di pedesaan yang kurang padat penduduk), urutan alternatif masih tetap sama yaitu: hydraulic jack-in pile 25,89\%; diesel hammer 25,37\%; dan vibratory hammer 19,87\%. Hal ini berarti hasil analisis tegap atau kuat sehingga hasil dapat dipercaya.

\section{KESIMPULAN}

Proyek pemancangan 238 titik sampai kedalaman $12 \mathrm{~m}$ menggunakan tiang pancang bujursangkar 25x25 cm @6 m pada tanah lanau di Pabrik Gula Trangkil Pati Jawa Tengah dilaksanakan menggunakan alat hydraulic jack-in pile. Upaya pemeriksaan kesesuaian penggunaan alat tersebut dilakukan menggunakan software Expert Choice. Tiga jenis alat yaitu: diesel hammer, vibratory hammer, dan hydraulic jack-in pile dibandingkan terhadap faktor-faktor pemilihan alat. Faktor-faktor tersebut adalah: dampak lingkungan (DL), biaya pelaksanaan (BP), jumlah tiang (JT), ukuran tiang (UT), karater tanah (KT), lokasi proyek (LP), topografi lokasi (TL), dan keberadaan alat (KA).

Hasil analisis menunjukkan bobot kriteria: DL 28,8\%; BP 22,8\%; JT 15,2\%; UT 10,7\%; KT 8,3\%; LP 5,8\%; TL 4,8\%; dan KA 3,6\% dengan inkonsistensi $2 \%(<5 \%)$. Urutan alternatif adalah:hydraulic jack-in pile, diesel hammer, dan vibratory hammer dengan bobot secara berurutan: 44,5\%; 28,7\%; dan 26,9\%. Analisis sensitivitas dilakukan dengan merubah bobot kriteria menjadi: DL 13,0\%; BP 14,1\%; JT 12,5\%; UT 11,2\%; KT 9,3\%; LP 12,4\%; TL 13,3\%; dan KA 14,2\%. Perubahan tersebut memberikan hasil urutan alternatif yang tetap dengan bobot: hydraulic jack-in pile 40,2\%; diesel hammer $31,2 \%$; dan vibratory hammer $28,6 \%$.

Berdasar analisis di atas, dapat ditarik kesimpulkan bahwa dengan menggunakan kriteria:DL, BP, JT, UT, KT, LP, TL, dan KA maka urutan alternatif alat pancang adalah hydraulic jack-in pile, diesel hammer, dan vibratory hammer. Besar bobot alternatif alat pancang adalah hydraulic jack-in pile = $44,5 \%$, diesel hammer $=28,7 \%$, dan vibratory hammer $=26,9 \%$. Hal ini berarti penggunaan alat hydraulic jack-in pile di lokasi proyek yang diteliti memiliki tingkat kecocokan 44,5\%.

\section{DAFTAR PUSTAKA}

Bowles, J. E., 1996. “Foundation Analysis and Design, Fifth Edition”. The McGraw-Hill Companies, Inc., Singapore, xxiii+1207p. 
PDCA (Pile Driving Contractors Association), 2003. "Driven Piles are Tested Piles". http://www.piledrivers.org/files/uploads/272d1300-0887-4849-bdb04044b9ff8859.pdf.accessed: 14-04-12.

UFC (Unified Facilities Criteria), 2004. "Pile Driving Equipment". U.S. Army Corps of Engineers, Washington, DC 20314-1000, v+1-16+2-29+3-58+4-14+5-19_A-1+B-1p.

Peurifoy, R. L., Schexnayder, C. J., and Shapira, A., 2006. "Construction Planning, Equipment, and Methods, Seventh Edition”. McGraw-Hill, New York, xvi+768p.

Assakkaf, I., 2003. "Piles and Pile-Driving Equipment". Department of Civil and Environmental Engineering, University of Maryland, College Park.

Manalu, A. P., 2012. "Analisa Pemilihan Alternatif Alat Pancang (Studi Kasus Proyek Aparteman Gunawangsa)”. http://digilib.its.ac.id/public/ITS-Undergraduate-191553109106048-Paper.pdf.accessed: 26-02-13.

Ishizaka, A. \& Labib, A., 2009. "Analytic Hierarchy Process and Expert Choice: Benefit and Limitations”. OR Insight, Vol. 22, No. 4, pp. $201-220$.

Bayazit, O. \& Karpak, B., 2005. “An AHP Application In Vendor Selection”. ISAHP 2005, Honolulu, Hawaii, July 8 - 10, 2005.

Atthirawong, W. \& MacCarthy, B., 2002. "An Application of the Analytical Hierarchy Process to International Location Decision-Making". http://www2.ifm.eng.cam.ac.uk/cim/imnet/papers202/Atthirawong.pdf.accessed: 0111-12.

Alanbay, O., 2005. "ERP Selection Using Expert Choice Software”. ISAHP 2005, Honolulu, Hawaii, July 8 - 10, 2005.

Adamovic, P., Dunovic, C., and Nahod, M. M., 2007. "Expert Choice Model For Choosing Appropriate Trenchless Method For Pipe Laying". http://bib.irb.hr/datoteka/348146.Adamovic_Dunovic_Nahod_Prag_09_2007.pdf.acce ssed: 01-11-12.

GRV, 2009. "Pile Info". http://www.geoforum.com/info/pileinfo/.accessed: 05-03-13.

Haseebjamal, 2013. "Pile Driving Equipment". http://www.aboutcivil.org/piledriving-equipment-hammers.html.accessed: 05-03-13.

Saaty, T. L., 2008. “Decision Making With The Analytic Hierarchy Process". Int. J. Services Sciences, Vol. 1, No. 1, pp. 83 - 98.

Saaty, T. L., 2000. "Fundamental of Decision Making and Priority Theory. 2nd ed.", RWS Publications, Pittsburgh, 478p.

Partovi, F. Y., 1994. "Determining What to Benchmark: An Analytic Hierarchy Process Approach". International Journal of Operations and Production Management, 14 (6), pp. $25-39$.

Saaty, T. L., 1977. "A Scaling Method for Priorities in Hierarchy Structure”. Journal of mathematical psychology, Vol. 15, No. 3, pp. $234-281$.

Millet, I. \& Saaty, 2000. “On the Relativity of Relative Measures-Accommodating both Rank Preservation and Rank Reversals in the AHP". European Journal of Operational Research, Vol. 121, No. 1, pp. 205 - 212. 